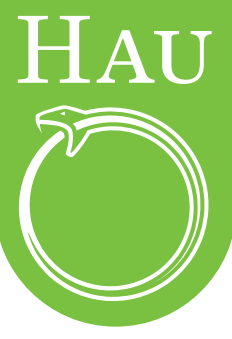

\title{
The power of ethnography in the public sphere
}

\author{
Thorgeir Kolshus, Oslo and Akershus University \\ College of the Applied Sciences / University of Oslo
}

A number of anthropology's most emblematic innovations have caught on elsewhere. Yet anthropologists seem almost distressed by the success of concepts like "culture" and "ethnicity" and too readily dispose of them in the name of scholarly fastidiousness. Lately, "ethnographic method" has gained multidisciplinary attention. Instead of providing guidance to the limits of ethnography, we engage in a search for the catchall definition, risking abandoning the vague-but-useful for the optimal-but-unattainable. In this article, I draw on my experience as a public anthropologist to show how ethnography, in the scholarly highly unsatisfactory meaning of "good stories," is crucial to our public engagements, which again triggers a curiosity to anthropology that the future of our discipline depends on.

Keywords: public anthropology, transdisciplinary impact, popularizing, academic writing

The HAU debate on ethnography was a thrill to attend. Finally, after three decades during which stifling self-scrutiny has been mistaken for a disciplinary virtue, we rekindle our forerunners' commitment to making a difference beyond our own intellectual shores. When this panel of distinguished anthropologists, of different backgrounds and with highly different research interests and epistemological bases, all adamantly unite behind our duty to engage a postfact age in dire need of nuances, this heralds a crucial change in orientation. In retrospect, the article that triggered the debate seems mistitled-“That's enough about introspection!" would be more fitting - and I believe many us will take Tim Ingold's primal scream for a rallying call, being just as "sick and tired of equivocation, of scholarly obscurantism, and of the conceit that turns the project of anthropology into the study of its own ways of working" (2014: 383). We have taken all that we need from the hodgepodge of critiques and turns, and time has come for that most social of the social sciences to recommit to its Enlightenment roots. This is the point where 
I, a decidedly mediocre scholar with an underwhelming publication record, find an entry and have the audacity to claim a seat at the table of my betters. Because I belong to that rare breed of anthropologists who engage the wider public on a regular basis and I have seen the impact or, as Daniel Miller thoughtfully prefers, "education" our discipline can have on popular perceptions of the world and what takes place in it. The future of many anthropology positions in academia depends on our ability to broaden these engagements, and in the longer term, the discipline itself is at risk. The year I started my anthropology studies, George Stocking Jr., that distinguished historian of our discipline, maintained that "despite the transformation of its traditional subjects, the blurring of its boundaries, the decentering of its discourse, it seems likely that the sheer force of institutional inertia, if nothing else, will maintain anthropology until well into the twenty-first century" (1992: 372). Twenty-five years later, institutional inertia no longer aptly characterizes university administrators' attitude toward anthropology, as many of our colleagues will attest to. Like all the panel members, I am convinced that the way ahead lies in clarity of communication-not only when engaging the public but also when addressing our peers. This involves modifying our award structure and culture of academic prestige. Put bluntly, we need to tell our students that to make ourselves understood is the essence of any academic involvement. As a case in point, I will provide a few examples from Norway, the academic culture that I know best.

\section{Suckers for anthropology, or just your regular audience?}

Several explanations have been given for the relatively prominent position anthropology has occupied in the Norwegian public sphere (see, for instance, Howell 2010; Eriksen 2006). ${ }^{1}$ Around 1900, more foreign missionaries per capita than any other nation combined with the world's second largest merchant fleet exposed many Norwegians, directly or by proxy, to the world beyond their shores. The gradual transition from foreign missions to foreign aid in the decades after WWII nurtured this international awareness. This predisposition to the relevance of global matters was capitalized upon by eager public involvements from prominent anthropologists. The efforts of Arne Martin Klausen and Fredrik Barth in the 1970s, followed by Unni Wikan, Marianne Gullestad, and Thomas Hylland Eriksen in later years, secured anthropology's place in the public sphere during the decades when student numbers exploded. Those of us who studied in the 1990s inherited an academic culture in which research dissemination, formidling, and participation in public debates on issues relevant to our studies (which, as we know, means virtually anything) was a matter of course. We have, in our turn, passed this on to our students. Every once in a while I hear remarks from American colleagues that there is no wonder anthropologists make our mark here, since compared to the United States, Norway is a village. This is a fair point. But the fact that we have an equally scaled-down market of popular attention is also part of the equation. I am a columnist with the largest Norwegian newspaper, Aftenposten, with a circulation

1. Why Norwegians' love affair with anthropology seems to be on the wane is the topic of a future article. 
of 220,000 and a daily readership of 800,000 - around $20 \%$ of the population over fifteen years of age-and I am also contacted by other newspapers, radio, and television for commentary on anthropology-related matters weekly, and I am far from being the most profiled of Norwegian anthropologists.

But how is this relevant to the ethnography debate? Well, in my experience, the contributions that go down best are without doubt the ones in which I include descriptions of people's lives, either on Mota, the Vanuatu island where I do my fieldworks, or other empirical matters. These usually contain comparative links to a contemporary Norwegian case, thus, in Geertz' elegant prose, “seeing particular things against the background of other particular things, deepening thus the particularity of both" (2000: 138). This is partly because ethnography entails good stories, this highly valued currency that we tend to take for granted because we are surrounded by people who all have plenty of it. But it also constitutes our disciplinary authority, which in Norwegian parlance is the opposite of synsing, "opinionated remarks." Put simply, when we speak ethnographically, we speak authoritatively. The same affection for ethnography is found in schools, in which the impact of academic anthropologists with a vision for formidling gradually has made its mark. First in the early 1970s, by securing that training in anthropology qualified for teaching geography, and then by gradually introducing anthropological perspectives in the social science subjects. The UK and the Norwegian system of secondary education are not easily compared, but numbers can nonetheless serve as indication of a trend. In the United Kingdom, A-level anthropology attracted 222 students out of 300,000 in $2014 .{ }^{2}$ In Norway, out of the 25,000 who followed the path that qualifies for university admission, almost half chose the option Sociology and Anthropology, more than for any elective subject. I have for the past few years been responsible for the school outreach of the anthropology department at the University of Oslo. When I ask the teachers what they want from us, the answer is unanimous: "We need the good stories!" Consequently, we have put together a team of former students who follow a script that leaves much room for their own fieldwork experiences. Feedback from teachers and team alike shows that the secondary students appreciate the set pieces and teaching points, but they love the field stories and consequent comparative lessons. Those who now fear that this is a traveling freak show of anthropological exoticizing might be relieved to learn that we pair them so that each team features a "traditional" and a "modern" type of fieldwork. The reflexive distance caused by comparative juxtaposing brings a remarkable learning effect.

Newspaper readers open to comparative long-shots? Seventeen-year-olds wanting to skip breaks in order to learn more of the outcome of ethnographic fieldwork? This does indeed sound like a peculiar breed of people. And true, long-term exposure to the popularizing efforts of academic anthropologists has left its mark. But there is no part of Norwegians' bodily or social constitution that make them more receptive to the lives of others, and they most certainly do not have a public culture that celebrates scholarly achievements and holds intellectuals in high regard-quite to the contrary, many might say. It is the same recipe for this achievement as for any

2. http://www.independent.co.uk/news/education/education-news/anthropology-becomes-latest-a-level-to-be-axed-10030033.html. 
other: a bit of inspiration and a lot of effort. As anthropologists, addressing issues that touch on people's lives and experiences, we enjoy a shortcut to popular attention shared by hardly any other academic discipline. The sales figures of J. D. Vance's Hillbilly elegy (2016) and Arlie Hochschild's Strangers in their own land (2016) in the wake of the US presidential election are a case in hand. Ours is indeed a powerful tool kit, applicable to a wide range of purposes. But the only authority behind our involvement derives from the raw material, or medium, which is ethnography.

\section{Fleeing from our successes}

This is also why I have read Tim Ingold's earlier contributions and listened to the debate with some consternation. Because it would be quite in our disciplinary character to start plucking at a key concept until it is left featherless and barely recognizable. We are indeed anxious about being relevant, but we also seem anxious when we become relevant. Put short, we rarely miss an opportunity to miss an opportunity. ${ }^{3}$ The message to prospective students and other anthro-curious members of the public is that we are too busy discussing our presence in the world to be bothered with actually engaging it. I felt this clearly when I wrote the sentences above regarding how the good stories were in great demand and had a visible impact: I already envisioned the barrage of criticism for flaunting my Western white male orientalist constitution in such an unapologetic manner, and deleted this section several times before deciding with much trepidation to include it. I was more concerned about whether I was saying something wrong than whether I was saying something important. The consequence of such instincts is abdication from intellectual domains that ought to be ours. As Signe Howell points out in this debate, we tend to disown our key contributions once they catch on elsewhere, carelessly dismissing the intellectual heritage from our forebears. ${ }^{4}$ As I write these words, I am involved in an ongoing media discussion on the concept of "ethnic Norwegian," triggered by a governmentally appointed panel's concern for what they call the "thick" aspects of Norwegian culture (i.e., enduring and nonmaterial, quite reminiscent of Dumont's concept of value) in an increasingly multicultural context. The "culture" that is debated is very much an anthropology-derived version-but it is one that we abandoned during the Writing Culture debate. And if I had taken the latest ruminations on ethnicity into consideration, I would never have been able to cut through the conceptual muddle by giving a brief recap of the seminal work of Fredrik Barth and his associates (1969) and apply it to a few experience-near (dare I say ethnographic?) cases. The discussion would have been much less informed, covered mainly by our social

3. Abba Eban coined this aphorism when commenting on the failed cooperation of the Arabic states.

4. My favorite parable for anthropologists' attitude toward past gains is Adelbert von Chamisso's 1814 novella "Peter Schlemihls wundersahme Geschichte." The protagonist sells his shadow to the devil in exchange for a never-ending cash flow, since he does not have any use for it anyway, only to find his new shadowless person shunned by everyone, for whom the presence of a shadow is part and parcel of being human (Chamisso 1836). 
science neighbors who are many more pieces short of the full(er) picture; the absence of anthropological perspectives might possibly have serious consequences for policy making; immigrants and their descendants, and adoptees with a skin color different from the majority, would find themselves perceived as forever non-ethnic Norwegian; and an obvious opportunity to promote the relevance of anthropology would be lost. Surely, the classic Barthian understanding of ethnicity might put too much weight on self-identification and too little on the ascribed aspects of ethnicity. And the invitation to constructive cooperation I sent to my main adversary, asking him to join in a conversation on the inalienable aspects of Norwegian culture, implied a concept of culture that would bring out the claws with most peer reviewers. But I got to say something important, even if it was not entirely "un-wrong."

If I had been socialized into a different academic tradition, where such engagements were not encouraged and possibly even disdained, my wading into this debate would have been unthinkable. Even knowing that my colleagues approve of public interventions, I applied unbracketed versions of "culture" and "ethnicity" with some hesitation. But "ethnicity" and "culture" are concepts that resonate far beyond academia because they deal with phenomena people can relate to-and as long as these concepts are associated with anthropology, they provide openings for more sophisticated analyses further down the line. This requires us engaging such concepts on a regular basis. When journalists, and the public, no longer associate "culture" with "anthropologists," we have bigger problems than applying a slightly more inaccurate understanding of a well-established term. Such narcissism of minor differences is intellectually incapacitating and is the surest way to irrelevance.

Similar experiences of anthropologists laying waste to our conceptual achievements give cause for concern now that Ingold has put "ethnography" in the critical spotlight. This is not because I believe he has no eye for the consequences, quite to the contrary. The pointed message in his Radcliffe Brown lecture (Ingold 2008), currently repeated with a few twists of the rhetorical screw, betrays a true concern for disciplinary matters. Too, the ethnographic credentials of the man who came up with what arguably is the most vital shorthand for our endeavor, "anthropology is philosophy with people in" (Ingold 1992: 696), are not as easily squandered as those of the one who paraphrases him accordingly: "So if, as [Ingold] notoriously said, anthropology is philosophy with people in it, I'd say he is right, but only without the people" (Holbraad 2010: 185). ${ }^{5}$ If anybody still had doubts, a decisive moment in the $H_{A U}$ debate proved them groundless. When Rita Astuti asked Ingold whether anyone could become an anthropologist without having done fieldwork, his answer was an emphatic and unconditional "No!" In other words, he does not suffer from the philosophyfilia that lately seems to have affected many our peers. ${ }^{6}$ But I still have concerns regarding the side effects of Ingold's provocative intervention. We

5. In all fairness, the context of this statement is the Manchester debates, in which the contributors are encouraged to be blunt for the sake of confrontation. But it is after all the very last sentence of Holbraad's prepared statement, and read with his frequent references to "theoretical mileage" in his much-read chapter on mana in mind (2007; see Kolshus 2016), it does seem more committed than contrived.

6. See Hertz (2016) for a wonderfully forthright criticism of Deleuze-inspired willful obscurantism. 
seem to nurture an academic culture (sic) and a disciplinary structure of rewards that encourage self-inflicted harm by people with a desire to make their mark. When provocation becomes convention, this is no longer a sign of vitality. It also leaves too much ground for attention-seeking (and dare I say male?) hyperbole, the academic equivalent of pressing the doorbell and running off giggling. What is more worrying is that such behavior seems to be career enhancing. In an interesting retrospective article, George Marcus (2007) readily acknowledges that he had never expected the Writing Culture critique to be taken so literally or that it would have such an impact. I suspect other critics, both within and outside of anthropology, have been surprised by the discipline's receptivity to reproach.

So if we in the coming decade gradually will suspend ethnography from uninhibited usage, because we half-remember that Ingold had an issue with the concept, it would certainly seem to fit the pattern of disowning our achievements. ${ }^{7}$ I moved from a "pure" social anthropology department to my current position in a multidisciplinary department only ten weeks ago. But in this short time, there have been no fewer than three different workshops on the "ethnographic method" in my place of work. Interestingly, when asked to specify what they mean by "ethnographic method," virtually everyone answers something like, "well, you know, anthropological methods." This usually involves observation, in classrooms or in hospital wards, complemented by interviews. One of the participants had been awarded her $\mathrm{PhD}$ based on what she unflinchingly presented as "ethnographic work in thirty schools in twenty-two countries." As is the case with culture concepts, we should be pleased with having others reap the benefits of our toils. It is most definitely a form of impact, in the spirit of the gift. But given that attention is a scarce commodity and convertible into student numbers and research funding, we might be too generous for our own good. We cannot reclaim ethnography for our own exclusive usage-but that does not mean that we should not acknowledge our parentage to it.

\section{The use-value of an underdefined concept}

But what is "it," exactly? That is hard to tell. And, as has been pointed out by several sympathetic readers both in the panel and beyond (see for instance Shryock 2016), Ingold's attempts to reach at a positive definition of ethnography are not immediately clarifying. We might settle with Roy Wagner's maxim, "the things we can define best are the things least worth defining" (1981: 39), or we must realize that we are dealing with the semantic effect Garrett Hardin labeled "panchreston," the "explain-all," a term that is so powerful that it accounts for everything and consequently accounts for nothing (1956). Maybe ethnography shares the fate of other old but useful tools and concepts, such as "cross-cultural comparison" and "holism,"

7. It is something of an irony that those who most uninhibitedly refer to ethnography are the ones engaged in the multispecies version (see for instance Kirksey and Helmreich 2010; Lien 2015; Tsing 2015). A number of those working in this tradition also seem to take Bruno Latour's claim regarding the supposed Western nature/culture distinction at face value, consequently reproducing what is probably the most unsophisticated Occidentalism in our disciplinary history. 
which elude attempts at pinpointing because they are closer to Aristotelian phronesis, "practical wisdom" or "praxis-enlightened knowledge" than to episteme (see Flyvbjerg 2001; Flyvbjerg, Landman, and Schram 2012)? In other words, we know when we get it right, we just don't quite know how we know it. This also seems to be the position taken by the three other panelists. And they were joined by Ingold in emphasizing a different sense of urgency that constitutes a make or break of anthropology, namely the requirement for a more open and accessible style of writing. ${ }^{8}$ Admittedly, the days when anthropological texts were so readable that Aldous Huxley could take for granted that the readership of Brave New World (1932) would be familiar with the Trobrianders' notions of procreation might never return. But it is a very long journey from Malinowski's, Mead's, and Evans-Pritchard's outreach to our current state, in which the number of trained anthropologists is at a historic high while most members of a generally enlightened public would struggle to name more than two of our living peers. And I seriously doubt that I am the only one who rarely finds a monograph that is not just an interesting read but a properly enjoyable one. ${ }^{9}$ What has come out of this discussion is a very clear message to our students that obscurity is a vice and not a virtue. It might be that Ingold's is a rather laborious cure for which there is not disease. But if it has the side effect of rekindling our commitment to making a difference in the world, we have indeed been witnessing Howell's "magic of serendipity" at play. Ethnography disciplines us and holds inclinations to moralism in check-which is important, because our main weapon in countering postfactualism is getting our facts straight by getting them as crooked as they come. We do this with a nod to comparison, which is constitutive of all pedagogy and which is also our most creative tool. I strongly believe that ethnographic rigidity and comparative creativity combined is what will keep our discipline agile, even in times of grand theoretical dry spells. This combination will also secure us an audience beyond our own ranks. And maybe that's enough said about ethnography?

\section{References}

Barth, Fredrik, ed. 1969. Ethnic groups and boundaries: the social organization of culture difference. Oslo: Universitetsforlaget.

Chamisso, Adelbert von. 1836. Werke. Vierter band. Gedichte. Adelberts Fabel. Peter Schlemihl. Leipzig: Weidmann'sche buchhandlung.

8. This is particularly true to those of us who are not native English speakers. The global academic market has turned our publishing culture into an arena for competition, in which quality is assessed not by virtue of the contents but by the number of other contributions your contribution has surpassed. Within such a regime, writing with a national academic or general public audience in mind appears almost disloyal to the project of advancing a department's institutional rating. Collateral damage of this shift in emphasis has been quality publications intended for a national audience, which means that our potential readership has contracted drastically.

9. Even in whining, I stand on the shoulders of giants. In his afterword to the revised edition of his Azande monograph, Evans-Pritchard complains how he would "find the usual account of field-research so boring as often to be unreadable” (1976: 254). 
Eriksen, Thomas Hylland. 2006. Engaging anthropology: The case for a public presence. Oxford: Berg.

Evans-Pritchard, E. E. 1976. Witchcraft, oracles, and magic among the Azande. Oxford: Clarendon Press.

Flyvbjerg, Bent. 2001. Making social science matter. Translated by Steven Sampson. Cambridge: Cambridge University Press.

Flyvbjerg, Bent, Todd Landman, and Sanford Schram, eds. 2012. Real social science. Cambridge: Cambridge University Press.

Geertz, Clifford. 2000. Available light. Princeton, NJ: Princeton University Press.

Hardin, Garrett. 1956. "Meaninglessness of the word 'protoplasm." ETC: A Review of General Semantics 13 (3): 193-208.

Hertz, Ellen. 2016. "Pimp my fluff: A thousand plateaus and other theoretical extravaganzas." Anthropological Theory 16 (2-3): 146-59.

Hochschild, Arlie. 2016. Strangers in their own land: Anger and mourning on the American right. New York: The New Press.

Holbraad, Martin. 2007. "The power of powder: Multiplicity and motion in the divinatory cosmology of Cuban Ifá (or Mana, again)." In Thinking Through Things: Theorising Artefacts Ethnographically, edited by Amiria Henare, Martin Holbraad, and Sari Wastell, 189-225. Oxon: Routledge.

—. 2010. "Against the motion: Ontology is just another word for culture." Critique of Anthropology 30 (2): 152-200.

Howell, Signe. 2010. "Norwegian academic anthropologists in public spaces." Current Anthropology 51, supplement 2: 269-77.

Huxley, Aldous. 1932. Brave new world: A novel. London: Chatto \& Windus.

Ingold, Tim. 1992. “Editorial.” Man, n.s., 27 (4): 693-96.

. 2008. "Anthropology is not ethnography." Proceedings of the British Academy 154: 69-92.

— 2014. "That's enough about ethnography!" HAU: Journal of Ethnographic Theory 4 (1): 383-95.

Kirksey, S. Eben, and Stefan Helmreich. 2010. "The emergence of multispecies ethnography." Cultural Anthropology 25 (4): 545-76.

Kolshus, Thorgeir. 2016. "Mana on the move: Why empirical anchorage trumps theoretical drift." In New Mana, edited by Matt Tomlinson and Ty Tengan, 155-82. Canberra: Australian National University Press.

Lien, Marianne E. 2015. Becoming salmon. Berkeley: University of California Press.

Marcus, George E. 2007. "Ethnography two decades after Writing culture: From the experimental to the baroque." Anthropological Quarterly 80: 1127-45.

Shryock, Andrew. 2016. "Ethnography: Provocation." Correspondences, Cultural Anthropology website. May 3, 2016. https://culanth.org/fieldsights/871-ethnography-provocation. 
Stocking, Jr., George W. 1992. The ethnographer's magic and other essays in the history of anthropology. Madison: University of Wisconsin Press.

Tsing, Anna Lowenhaupt. 2015. The mushroom at the end of the world. Princeton, NJ: Princeton University Press.

Vance, J. D. 2016. Hillbilly elegy: A memoir of a family and culture in crisis. New York: HarperCollins.

Wagner, Roy. 1981. The invention of culture. 2nd ed. Chicago: University of Chicago Press.

\section{Le pouvoir de l'ethnographie dans l'espace public}

Résumé : Parmi les innovations les plus emblématiques de la discipline anthropologique, plusieurs ont été adoptées dans d’autres domaines. Cependant, les anthropologues semblent presque inquiets du succès connus par les concepts de "culture," d"'ethnicité" et même parfois sur le point de les évacuer entièrement de leur discours au nom de la rigueur académique. Dernièrement, la "méthode ethnographique" a suscité l'attention de plusieurs disciplines. Au lieu d'assumer un rôle de conseil par rapport aux limites de l'ethnographie, nous avons entamé ce qui semble être une quête pour la définition la plus englobante, en risquant d’abandonner une notion vague mais utile pour une notion optimale mais inatteignable. Dans cet article, je mappuie sur mon expérience d’anthropologue public pour montrer comment l'ethnographie, dans son sens académique, et hautement insatisfaisant, de "récits passionnants" est essentiel à notre engagement public, qui engendre une curiosité pour l'anthropologie dont le futur de notre discipline dépend

Thorgeir Kolshus has worked ethnographically on the island of Mota in north Vanuatu since 1996, complemented by archival work. His research has mainly dealt with the relation between religion and politics in its widest sense. In recent years, he has published numerous articles on notions of mana, both contemporary and historically, which gained anthropological notoriety with Robert H. Codrington's ethnographic work from Mota. Kolshus is currently completing a monograph on developments of the concept of the soul, in Mota ethnography and in anthropology.

Thorgeir Kolshus

Department of International Studies Oslo and Akershus University College of the Applied Sciences Postboks 4 St Olavs Plass 0130 Oslo Department of Social Anthropology University of Oslo Postboks 1091, Blindern 0317 Oslo Norway

thorgeir.kolshus@sai.uio.no 